$11-2020$

\title{
Right-to-Work Laws as Economic Freedom: Their Role in Influencing the Geographic Pattern of Manufacturing Jobs, Incomes, and Finances
}

\author{
Richard J. Cebula \\ George Mason University, Fairfax, Virginia \\ John E. Connaughton \\ University of North Carolina at Charlotte \\ Caroline Swartz \\ University of North Carolina at Charlotte
}

Follow this and additional works at: https://digitalcommons.newhaven.edu/americanbusinessreview

\section{Recommended Citation}

Cebula, Richard J.; Connaughton, John E.; and Swartz, Caroline (2020) "Right-to-Work Laws as Economic Freedom: Their Role in Influencing the Geographic Pattern of Manufacturing Jobs, Incomes, and Finances," American Business Review. Vol. 23 : No. 2 , Article 12.

DOI: $10.37625 / a b r .23 .2 .431-450$

Available at: https://digitalcommons.newhaven.edu/americanbusinessreview/vol23/iss2/12 


\section{Right-to-Work Laws as Economic Freedom: Their Role in Influencing the Geographic Pattern of Manufacturing Jobs, Incomes, and Finances}

\section{Cover Page Footnote}

We are grateful to the Editor and anonymous referees for encouragement and helpful suggestions. 


\section{Right-to-Work Laws as Economic Freedom: Their Role in Influencing the Geographic Pattern of Manufacturing Jobs, Incomes, and Finances}

American Business Review Nov. 2020, Vol.23(2) 431 - 450

(c) The Authors 2020, CC BY-NC ISSN: 2689-8810 (Online) ISSN: 0743-2348 (Print)

\author{
Richard J. Cebula a, John E. Connaughton ${ }^{\text {b }}$, and Caroline Swartz ${ }^{\text {b }}$ \\ https://doi.org/10.37625/abr.23.2.431-450
}

\begin{abstract}
A large empirical literature has found positive effects from economic freedom on economic outcomes, such as output and per capita economic growth. This study seeks to explain empirically the disparate timing of state manufacturing earnings and employment decline, as well as the shift among states in both manufacturing earnings and manufacturing employment resulting from right-to-work laws, which can be viewed as reflecting labor market freedom and thereby acting as a de facto economic policy. The results of the empirical estimations suggest a marked geographic shift of manufacturing employment and compensation in the U.S. during the 1970 to 2012 time period. The empirical estimations indicate that the regions of the country that have historically represented the manufacturing base have suffered the greatest relative losses in both employment and compensation during this period. In addition to regional location, it appears that right-to-work laws have had the effect of leveling manufacturing employment and compensation levels across the states since 1970. The data analysis suggests that, at least in part due to right-to-work laws, the manufacturing sectors of the states and regions are becoming increasingly similar over time, i.e., manufacturing activity that was once highly concentrated in the Great Lakes, Northeast, and Mideast has now converged significantly, with the outcome that there is little geographic difference in concentration among the eight BEA regions.
\end{abstract}

\title{
KEYWORDS
}

Manufacturing Jobs, Manufacturing Earnings, Right-to-work Laws, Percent Rural Population, Geographic Differentials in Employment, Geographic Differentials in Compensation

J.E.L. Codes: R11; R12

\section{INTRODUCTION}

The Bureau of Economic Analysis (2018A; 2018B), BEA, maintains regional economic data for states as far back as 1929. Annual Income, Earnings, and Earnings by industry are available on an annual basis by state from 1929 through 2017 (Tables SAINC1, SAINC4, SAINC5, and SAINC7). Data for compensation of employees by industry are available from 1958 through 2017 (Table SAINC6). In addition, full-time and part-time employment and wage and salary according to industry data are available (Tables SAINC25 and SAINC27) from 1969 through 2011. These seven series provide a wealth of information with which to compare economic activity, reflecting among other things various dimensions of business health, across states and to look at changes in the patterns of state data over time.

\footnotetext{
a George Mason University, Fairfax, Virginia

b University of North Carolina at Charlotte

Corresponding Author:

Cebula (dr.richardcebula@gmail.com)
}

We are grateful to the Editor and anonymous referees for encouragement and helpful suggestions. 
This study reflects upon patterns revealed in state manufacturing income, earnings, and employment over time and across state and regional divisions. More specifically, it examines the shift in manufacturing activity over time in the U.S., i.e., it focuses upon trends in state manufacturing income, earnings, and employment over time, and at the resulting changes in manufacturing rank and position among states over both the 88 year period from 1930 through 2017 and the more recent 48 year period from 1970 through 2017 (during which more detailed data are available).

Given the observations by Murphy (2020, p. 65) that a "... large empirical literature has found positive effects of economic freedom on economic outcomes, such as output and per capita growth" and by Ghosh and McCannon (2017, p. 209) that "It has been well established that economic freedom is associated with good economic outcomes," we investigate the impact of right-to-work laws, which can be viewed as a precursor to the labor market freedom indices and as a de facto public economic policy (Cebula, 1980, 1989; Hogan, 1984; Stansel and McMahon, 2013; Stansel, Torra, and McMahon, 2018), on reduced geographical differences in manufacturing related-outcomes.

Since 1930, there have been significant changes in earnings from manufacturing as a share of total nonfarm earnings. In 1930, $25 \%$ of all nonfarm earnings were generated by manufacturing. The share of earnings from manufacturing increased until 1960, after which it decreased. By 2017 , only $11.9 \%$ of all nonfarm earnings came from manufacturing, as shown in Table 1.

Table 1. Earnings in Manufacturing as a Share of Total Nonfarm Earnings

\begin{tabular}{|c|c|c|c|c|c|c|c|c|c|c|}
\hline & 1930 & 1940 & 1950 & 1960 & 1970 & 1980 & 1990 & 2000 & 2010 & 2017 \\
\hline US & $25.0 \%$ & $26.3 \%$ & $29.0 \%$ & $29.5 \%$ & $26.5 \%$ & $24.5 \%$ & $19.1 \%$ & $15.6 \%$ & $9.9 \%$ & $11.9 \%$ \\
\hline
\end{tabular}

The states generally follow a similar pattern: increasing shares of earnings from manufacturing for a period of time, followed by a decline in the role of manufacturing. The timing of the manufacturing downturn varies across regions and states. Figure 1 below shows the number of states reaching their maximum share of earnings from manufacturing by year.

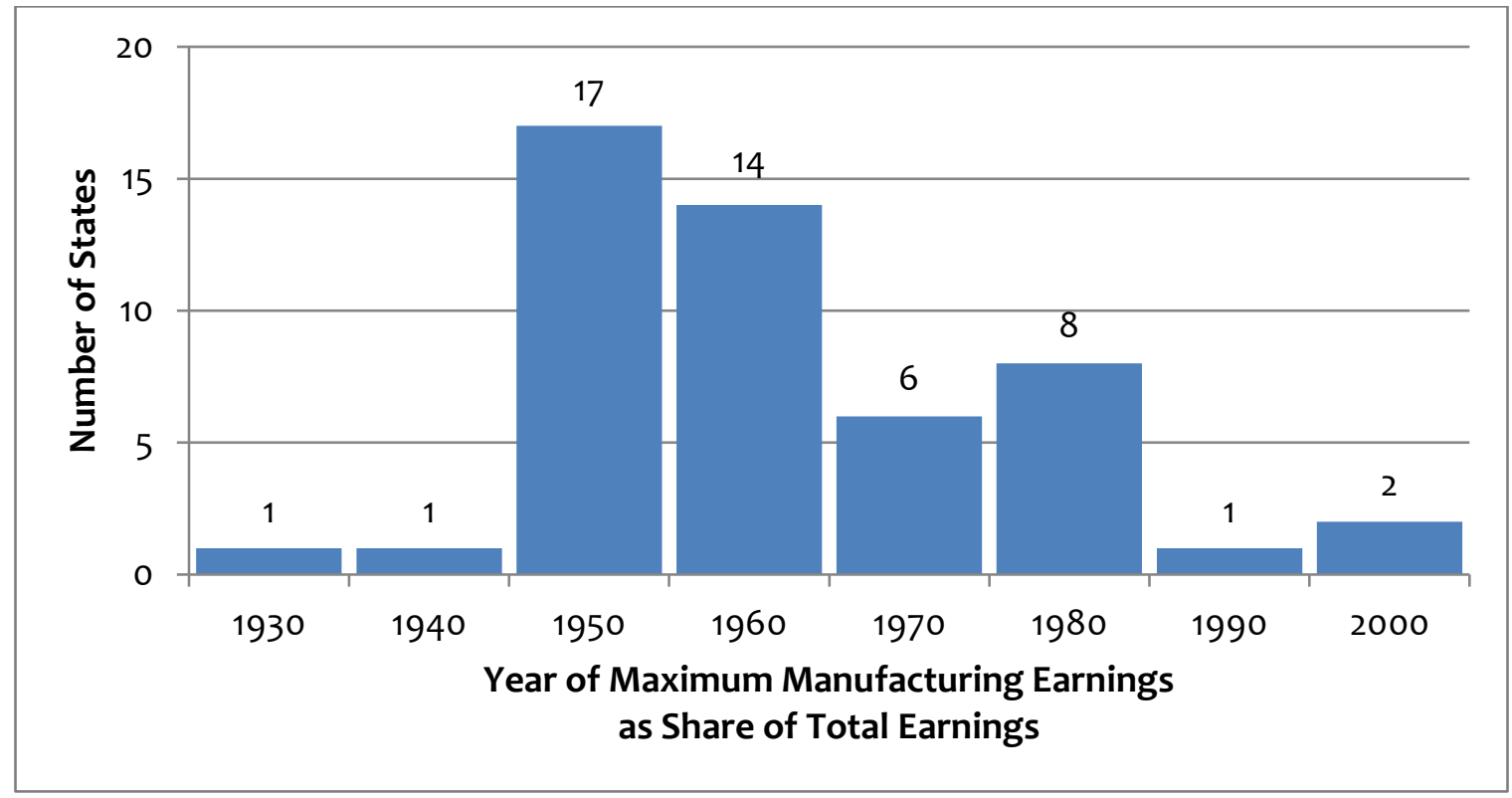

Figure 1. Number of States Reaching Maximum Share of Nonfarm Earnings from Manufacturing by Year 
The timing of the maximum percentage of earnings from manufacturing varies substantially across regions. For example, each of the six New England states reached its maximum share of earnings from manufacturing in 1950, whereas in the Plains region, the maximum share of earnings from manufacturing occurred between 1980 and 2000.

Manufacturing employment changes across states demonstrate a similar pattern over time. State-specific employment data for industrial sectors are only available from 1969 on; consequently, the considering of changes in employment misses some important milestones during the early period of manufacturing decline. However, these employment data do help in understanding how employment has shifted amongst the states during the past four decades.

This study seeks to investigate empirically the disparate timing of state manufacturing earnings and employment decline, as well as the shift among states in manufacturing earnings and manufacturing employment resulting from the implementation of right-to-work laws, which can be viewed not only as reflecting labor market freedom (Cebula, 1980, 1989; Hogan, 1984; Reed, 2003; Vedder, 1976, 2010; Stansel, Torra, and McMahon, 2018) but also serving as a de facto exogenous public economic policy. Two parallel model specifications are estimated. For reasons provided below, the equations were estimated for the period between 1970 and 2012.

\section{LITERATURE REVIEW AND BACKGROUND}

From a variety of differing viewpoints, modeling perspectives, and theoretical approaches, there has been a literature that for a number of years has focused on geographic differentials in the pattern of income and income growth, whether that pattern differential was treated as involving GDP per capita differentials between nations (Barro and Sala-Martin, 1992) or was treated as involving per capita income or wages within nations (Gatons and Cebula, 1972; Gallaway and Cebula, 1973; Martin and Sunley, 1998; Weber and Domazlicky, 2006). Moreover, the potential impact of right-to-work legislation (RTW) on geographic differentials in wages and productivity as well as income and employment has been investigated by a number of studies (Newman, 1983; Reed, 2003; Glaeser and Tobio, 2008; Stevans, 2009; Vedder, 1976, 2010; Hicks, LaFaive, and Devaraj, 2016).

In an earlier study of the effects of RTW legislation, Newman (1983) focused on such laws in the South from the late 1940 s through the 1970s. His empirical estimations appeared to reveal that this form of legislation contributed significantly to population growth rates. The latter was a consequence of labor-intensive manufacturing firms that decided to move to states adopting RTW statues so as to help minimize production costs and thereby elevate profitability.

Reed (2003) investigates the wage rate impacts of RTW legislation using state-level data. He finds that, other things held the same, RTW states have average wage rates that are significantly higher than do non-RTW states. Furthermore, this result is found to be robust is across a variety of specifications. An important feature of this study is that it controls for state economic conditions during the year that states adopted RTW, states that adopted RTW being generally poorer than other states. According to Reed (2003), failure to control for these initial conditions may be the underlying reason that previous studies did not find a positive wage impact resulting from RTW legislation.

The study by Glaeser and Tobio (2008) finds that during the half century preceding their study population and incomes have increased steadily throughout much of the Sunbelt region of the U.S., which is consistent with Gallaway and Cebula (1973). The Glaeser and Tobio study endeavors to assess the relative contributions of rising productivity, rising demand for Southern amenities, and increases in housing supply on the growth of warm areas of the U.S., using data on income, housing prices, and population growth rates. It is found that prior to 1980, economic productivity increased significantly in the warmer regions of the country and drove the population growth rates in those places. Since 1980, however, it is found that productivity growth has been more modest, whereas housing supply 
growth has been very extensive. It is concluded that that new home construction in warm regions represents a growth in supply, rather than in demand, from the fact that new housing prices are generally quite low vis-à-vis the remainder of the U.S.

Stevans (2009) observes that following passage and implementation of the Taft-Hartley Act, a dozen states quickly passed "right-to-work" laws--as did ten more states in the ensuing years. She further notes that whereas there has been considerable research on the effect of right-to-work laws on union density, organizing efforts, industrial development and some study of wage differences, there has been little or no examination of the legislation's influence on business and economic conditions across states.

Accordingly, Stevans focuses upon the average differences in business conditions, employment, personal income, wages, salaries, and proprietors' income across states that have enacted RTW versus those states that did not do so. The estimation process is conducted assuming that the legislation is endogenous and controlling for state real economic growth, region, and year. It is found that while right-to-work states may be more attractive to business, this fact does not necessarily translate into enhanced economic vitality in the presence of RTW if there is little "trickle-down" from business owners to the non-unionized workers. Stevans (2009) finds that the number of self-employed is higher and the rate of business bankruptcies lower on average in RTW states, but that there is no significant difference in capital formation or employment rates. Furthermore, per capita income and nominal wages are both found to be lower in RTW states, and proprietors' income is higher in RTW states. Of course, the latter two sets of results are potentially questionable since they do not account for geographic living-cost/price differentials (Cebula, 1989). In any event, one interesting dimension of this study by Stevans was the effort to allow for potential endogeneity of RTW laws.

In his study of the effects of right-to-work laws, Richard Vedder (2010) outlines the classical-liberal argument regarding workplace liberty and offers empirical evidence of the positive effects of RTW legislation on both employment and output in individual states. He finds that RTW laws have a positive impact on both jobs and output as firms and workers move to states with greater degrees of economic freedom and where labor market transactions can potentially be more efficiently undertaken.

It is noteworthy that a more recent study by Hicks, LaFaive, and Devaraj (2016) seeks in part to extend Vedder (2010) by investigating the impact of RTW laws on productivity (and population growth). The study begins with a review of the literature on both issues. The authors estimate a CobbDouglas production function for manufacturing industries at the state level and find that total factor productivity in non-RTW states was less than in RTW states. Their derivation of the Solow residual seemingly suggests that non-RTW manufacturing productivity was roughly 64 percent of that found in the RTW states. Furthermore, their firm-level analysis from the 2007 Survey of Business Owners finds that RTW states achieved higher productivity (sales per employee) than firms in non-RTW states. These results extend Vedder's (2010) examination of productivity of RTW laws across different estimation strategies while integrating a procedure to adjust for the potential endogeneity of RTW laws into their analysis as in Stevans (2009). Nevertheless, this treatment of RTW is effectively at odds with Stansel and McMahon (2013) and Stansel, Torra, and McMahon (2018), as well as Cebula (1980), Hogan (1984), and other studies.

Outside the scope of RTW legislation per se, geographic differentials in wages, productivity, income, and unemployment rates have been considered within the context of alternative model specifications and alternative types of variables. For example, the neo-classical model used by Barro and Sala-i-Martin (1992) yields strong evidence of a pattern of significant unconditional convergence of per capita GDP among nations over time (1880 to 1988). Implicitly, although not expressly acknowledged, this economic pattern is recognized as having been promoted to some significant extent by both internal and international labor migration on the one hand (Gatons and Cebula, 1972; Gallaway and Cebula, 1973; Martin and Sunley, 1998; Kane, 2001; Weber and Domazlicky, 2006) and, 
possibly, by the pattern of rapid convergence in the agriculture sector, as opposed to the manufacturing sector, of many economies on the other hand (Martin and Mitra, 2001, p. 418). In point of fact, Bernard and Jones (1996) even argue that, in addition to factor mobility, it is the service sector (rather than the manufacturing sector, to be discussed below) that has been the factor responsible for generating economy-wide convergence.

It is noteworthy that the model specification by Barro and Sala-i-Martin (1992) has been found to have potentially very serious shortcomings (e.g., Quah, 1993, pp. 426-429; Fingleton and McCombie, 1998). Furthermore, Gallaway and Cebula (1973) and Martin and Sunley (1998) find compelling evidence of per capita income convergence over time within nations and identify the critical role played in that convergence process by labor mobility but find that the convergence is incomplete, i.e., limited, arguably due to "mobility cost constraints," i.e., labor market costs that restrict mobility and that must be overcome by sufficiently large geographic earnings differentials in order to induce migration flows. Mobility costs not-withstanding, Weber and Domazlicky (2006, p. 31) argue that ultimately "... the traditional neoclassical growth model... applied in a regional context implies that regional convergence is a natural result of factor mobility,"

At a less aggregated level, there is a large and diverse literature addressing geographic trends in manufacturing, including a focus on economic growth broadly defined, and trends in manufacturing employment, labor productivity in manufacturing, and labor earnings in manufacturing, as well as interregional convergence, whether it be across nations or other political frameworks, with a frequent focus on the role of technology in convergence or the lack thereof. As Rodrik (2013, p. 165) has observed, "... neoclassical growth theory establishes a presumption that..." nations possessing equal access to identical technology should converge to a common level of real income." Rodrik (2013, p. 165) adds "However, empirical work has not been kind to this proposition." The latter observation is reflected either directly or indirectly in the findings of most, but not all, of the studies briefly summarized below. As Madsen and Timol (2011) observe, until very recently, despite the existence of major (and often elaborate) models of economic growth, most of the published research on comparative productivities find little or no compelling evidence indicating convergence in manufacturing among OECD nations.

As an example of this perspective, nearly 25 years ago, a study by Broadberry (1993) empirically compared labor productivity trends in the manufacturing sectors of three major industrialized nations, the U.S, Great Britain, and Germany. Adopting a historical perspective, he finds evidence of a persistent and large labor productivity gap in manufacturing between the U.S. on the one hand and both Great Britain and Germany on the other hand. By contrast, however, he finds that labor productivity trends in manufacturing per se are quite different from the experience of convergence of real GDP per worker over time among these three nations, suggesting then that the persistent gap in labor productivity is associated with technological choices and decisions, which is consistent with arguments proffered by Vedder (1976) and Tomiura (1997). In any event, the Broadberry (1993) study is a standard example of a rigorous empirical investigation finding labor productivity in manufacturing as not converging across member nations of the OECD.

Carree, Klomp, and Thurik (2000) empirically investigate the issue of convergence of average labor productivity across manufacturing industries in 18 OECD nations for the study period 1972 through 1992. Carree, Klomp, and Thurik (2000, p. 344) obtain results indicating “...large inter-industry differences in the extent of convergence." One important reason for these differentials in average labor productivity "... is knowledge and capital barriers preventing the occurrence of catch-up." This finding resembles, at least in principle, the impact of the mobility cost constraint on labor migration referred to above (Gatons and Cebula, 1972; Gallaway and Cebula, 1973). In any event, Carree, Klomp, and Thurik (2000) find evidence strongly implying non-convergence of labor manufacturing productivity. 
Somewhat similarly, Togo (2002, p. 66) found among the 12 major industries of Japan "... a variety of ergodic distributions of labor productivity." From this finding, Togo (2002, p. 66) he unreservedly observes that "This confirms previous findings that manufacturing does not display a pattern of convergence." Indeed, Togo (2002) seriously questions the practical relevance of the neoclassical growth theory paradigm.

The study by Miketa and Mulder (2005) provides an empirical investigation of energy-productivity convergence in ten manufacturing sectors across 56 developing and developed nations. Miketa and Mulder (2005) focus on a study period that runs from 1971 through 1995. Much like the studies of manufacturing sectors as a whole across nations by Broadberry (1993) and Carree, Klomp, and Thurik (2000), the results from this particular study indicate that cross-country differentials in energyproductivity performance are for the most part very persistent and that genuine convergence is not the general rule.

Interestingly, in the midst of these high-quality analyses is another high-quality analysis by Martin and Mitra (2001), which contrasts the productivity growth in manufacturing and agriculture. This study provides estimates of total factor productivity (TFP) growth in both the agricultural and manufacturing sectors in a variety of nations; the analysis investigates to what degree productivity growth converges in each of these two sectors. A data-set involving approximately 50 nations over the period 1967-1992 is examined. Although revealing high levels of technical progress in both sectors, the findings indicate that technical progress is faster in the agricultural sector than in the manufacturing sector. Moreover, the estimates very compellingly reveal convergence in both levels and growth rates of TFP in agriculture but not in manufacturing. Indeed, Martin and Mitra (2001, p. 417) argue convincingly that, in contrast to manufacturing, "... the results suggest a tendency for relatively rapid convergence in agricultural productivity across countries, implying a relatively efficient transmission (in contrast to manufacturing) of knowledge in modern agriculture." Thus, once again, the convergence hypothesis does do play out well with manufacturing.

The above studies not-withstanding, three more recent studies arrive at rather very different conclusions regarding convergence than do the aforementioned studies. The first of these studies is that by Weber and Domazlicky (2006, p. 44), who empirically investigate "... the role of the manufacturing sector in promoting regional convergence [in the U.S.], especially as it relates to labor productivity." Weber and Domazlicky (2006) focus upon the 50 U.S. states over the time period from 1977 through 1996 using data on the manufacturing sector. Weber and Domazlicky (2006, p. 31) begin by observing that "While the relative position of the manufacturing sector in the economy has declined over the past three decades, its importance to regional economic growth... is undeniable." Weber and Domazlicky (2006) then proceed to find compelling empirical evidence that labor productivity in manufacturing was converging over the 1977-1996 time frame. Based upon their results, they also provide the reader with a number of policy options that can promote greater labor productivity.

The second of these studies is that by Madsen and Timol (2011), who use manufacturing data for 19 OECD nations over the time period spanning from 1870 through 2006, a period of greater length and of course more current than that found in the study by Barro and Sala-i-Martin (1992). The Madsen and Timol (2011) study finds very robust evidence of unconditional convergence in manufacturing. Panel data estimations imply that this unconditional convergence has over time been driven by both domestic R\&D ("research intensity") and international R\&D spillovers resulting from the import of technology from the relatively more research-intensive nations. In addition, financial development (in conjunction with factor mobility) plays a significant role in the process of this convergence.

Finally, to round out this brief literature summary, there is the study by Rodrik (2013), cited earlier in this section of our study. In contrast to most of the existing literature, arguably with the most 
notable exceptions being Weber and Domazlicky (2006) and Madsen and Timol (2011), Rodrik (2013) finds extremely compelling evidence that manufacturing industries manifest very strong unconditional convergence in labor productivity. The empirical evidence involves a number of degrees of disaggregation for a large sample that involves 118 nations over recent decades. Moreover, this powerful gravitation towards unconditional convergence in labor productivity in manufacturing holds up regardless of geographic considerations, public policies, and most other nation-level influences.

Noteworthy among the more specific findings in Rodrik (2013, p. 202) is that manufacturing enterprises, even if they "... produce just for the home market... operate under a competitive threat from efficient suppliers from abroad, requiring that they upgrade their operations and remain efficient," an observation that would seem to reflect the idea of the "invisible hand." Also of possible interest, is the observation by Rodrik (2013, p. 202) that "Traditional agriculture, many non-tradable services, and especially informal economic activities, do not share..." this trait. Thus, the findings in Rodrik (2013) appear to be at odds with those in the earlier study by Martin and Mitra (2001) regarding traditional agriculture and manufacturing and, more specifically, the findings in Martin and Mitra (2001, p. 417) that there is ".... a tendency for relatively rapid convergence in agricultural productivity across countries, implying relatively efficient transmission (in contrast to the manufacturing sector) of knowledge in modern agriculture."

\section{DATA AND INITIAL ANALYSIS}

The present study adopts state-level data on compensation and employment from BEA Regional Accounts, Tables SAINC6 and SAINC27. The record of compensation in manufacturing dates back to 1930 while the employment data begins in 1970. As Figure 2 shows, the longer history of compensation demonstrates the expansion and subsequent decline in manufacturing, so this initial analysis considers the entire compensation series. By contrast, the employment picture since 1970, as shown in Figure 3 , reveals only the decline in manufacturing employment.

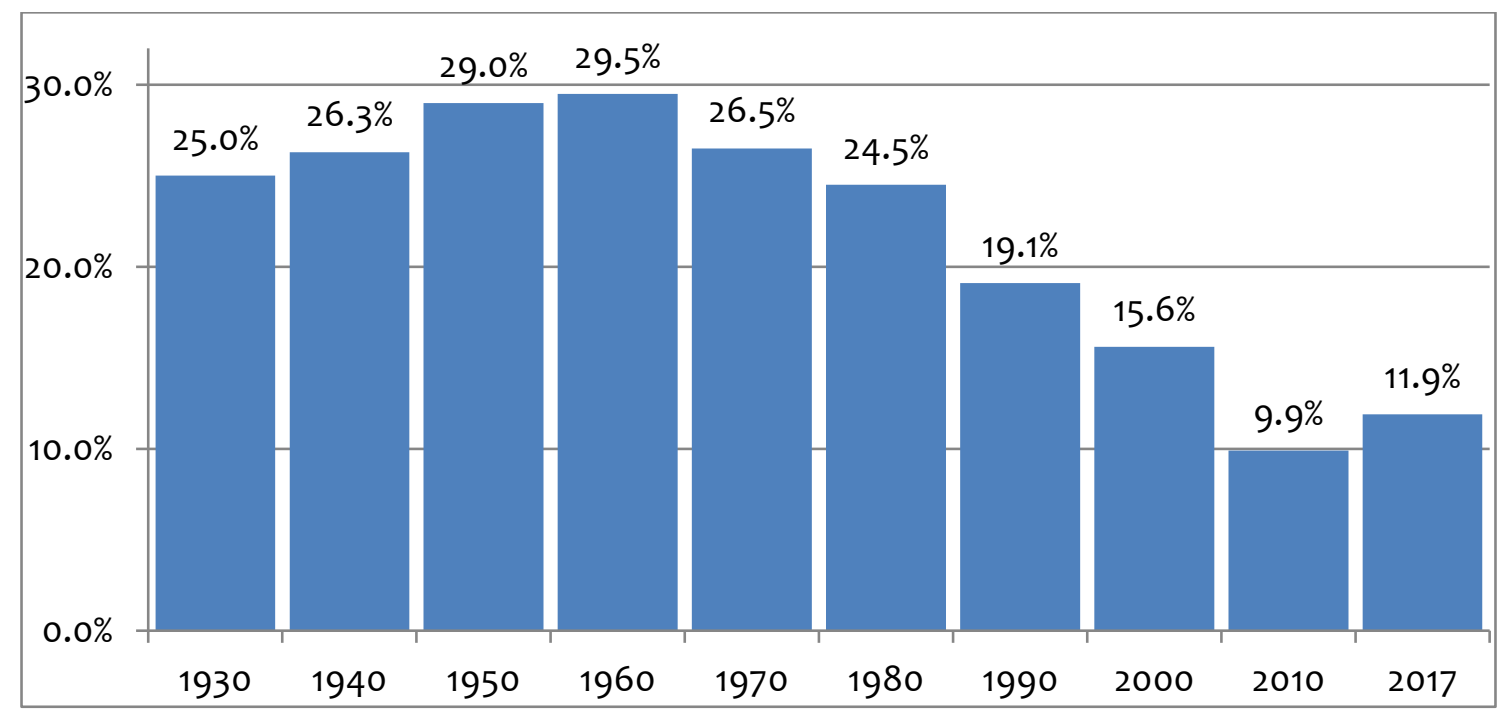

Figure 2. Share of U.S. Manufacturing Earnings in Non-Farm Earnings 


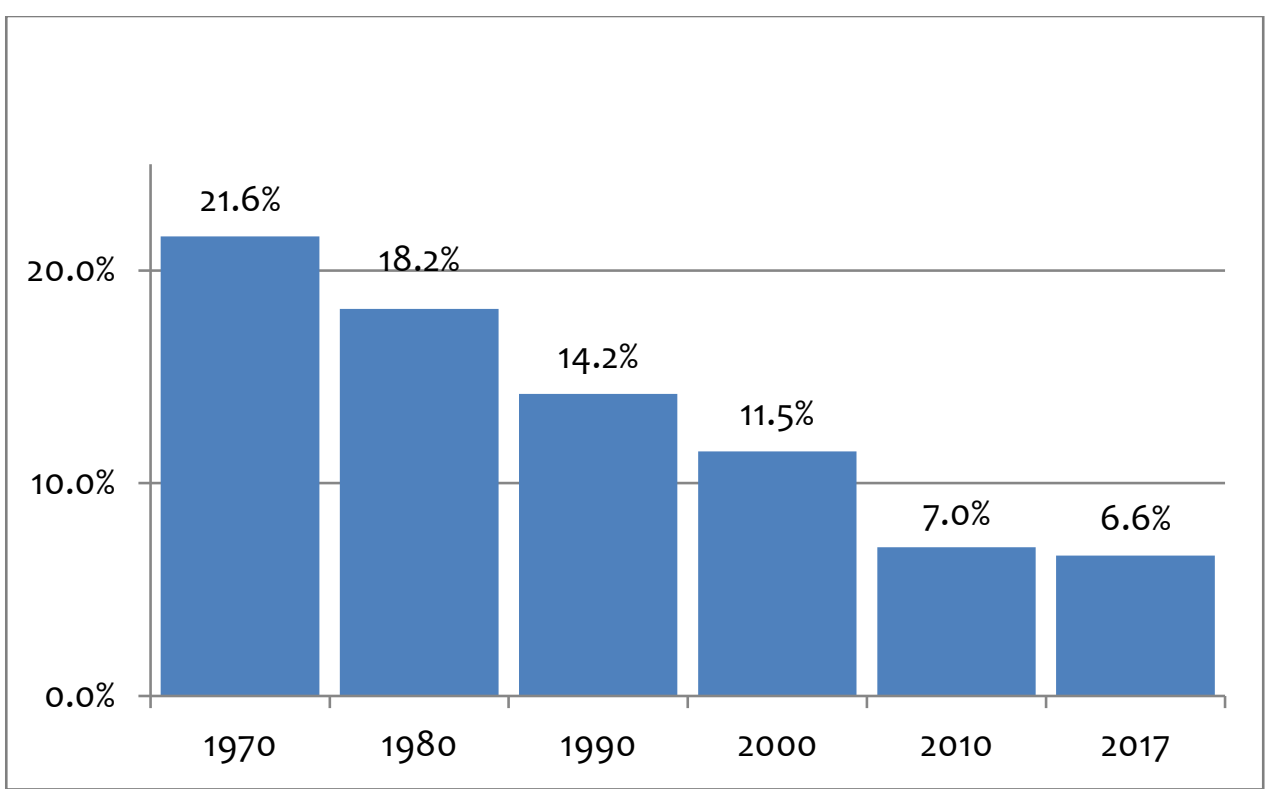

Figure 3. Share of U.S. Manufacturing Employment in Non-Farm Employment

Looking at the data on a regional basis, we see that the earnings in manufacturing have been highest in the Great Lakes region and lowest in the Southwest and Rocky Mountain regions, as shown in Figure 4. The share of manufacturing compensation in total non-farm compensation generally increased from 1930 to 1950 (New England, Mideast, Great Lakes, and Southeast) or 1960s (Rocky Mountains and Far West). Manufacturing's percentage share of non-farm income reached its peak in the Plains region in 1980. Similarly, the range of values increased from $27.1 \%$ in 1930 to a maximum of $28.8 \%$ in 1950 , declining to $11.0 \%$ by 2017 . In 1950, manufacturing compensation as a percent of total compensation in the Mideast region was 43.1\%, the highest of any region in that year. By 2017, manufacturing compensation as a percent of total compensation in the Mideast region had fallen to $9.0 \%$ which was the lowest of all the regions in that year.

An examination of the state-level data shows that in the Northeast region, the share of compensation from manufacturing started at a relatively high percentage and that it declined most rapidly beginning in the year 1980 . This is consistent with the finding by Sherwood-Call (1996) that the divergence among state per-capita personal income in 1980 can be explained, at least in part, by a shock to the Northeastern states. Many states in the Southeast also experienced a decline in the share of compensation from manufacturing after 1980. 


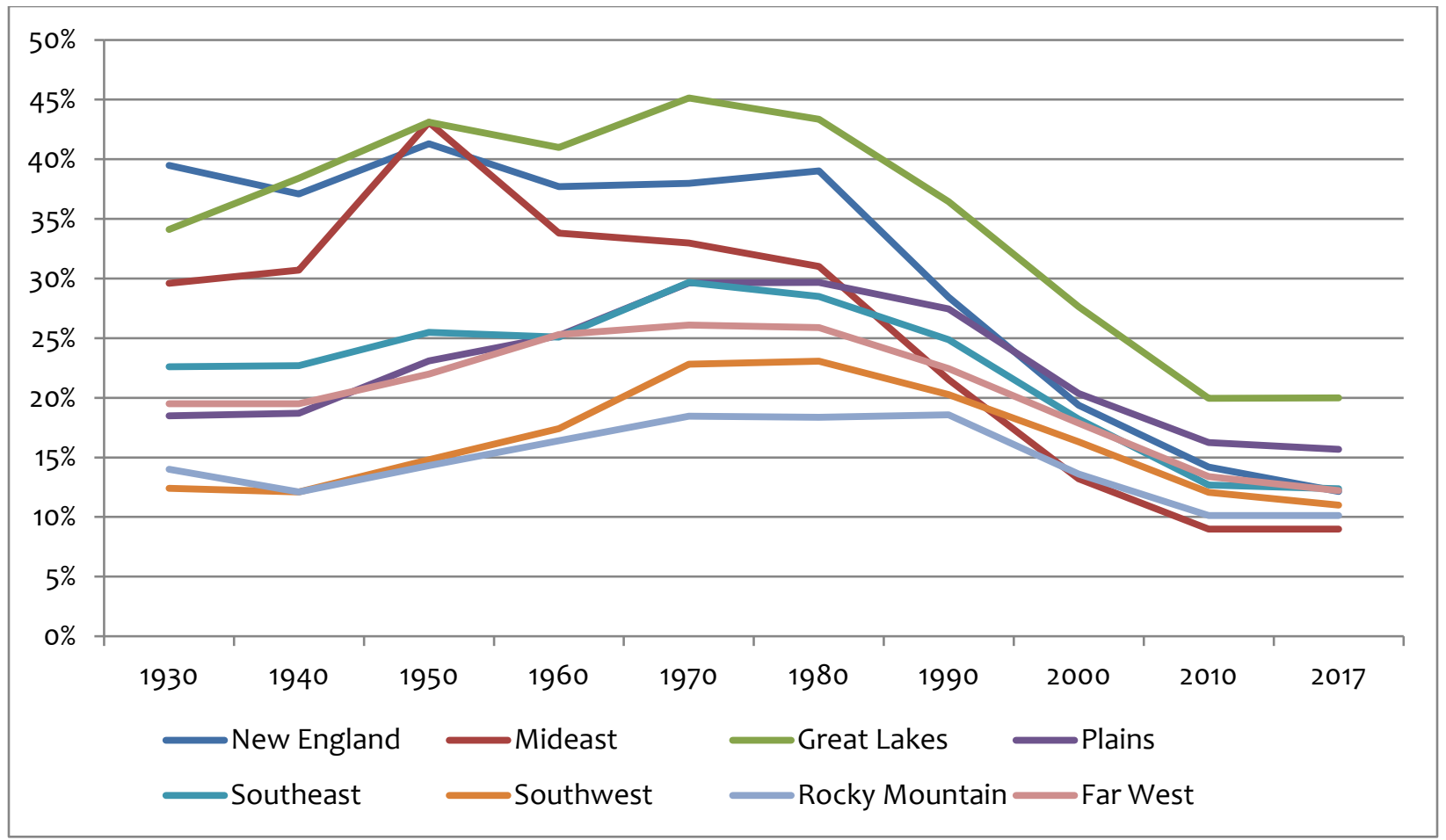

Figure 4. Share of Manufacturing Earnings in Non-Farm Earnings by Region

The share of manufacturing compensation is comparatively low in the Plains region states, never reaching 30\%. The level of manufacturing compensation is even lower in the Southwest and Rocky Mountain region, where the share of manufacturing compensation is below $20 \%$ during the study period.

Table 2 shows the year that each state achieved its maximum ratio of manufacturing compensation to non-farm compensation. Only two states, Florida (1930) and Maryland (1940), achieved their peak before 1950, and only three states, New Mexico (1990), North Dakota (2000), and South Dakota (2000), reached their respective peaks after 1980. For the remaining 45 states, the maximum ratio was achieved between 1950 and 1980. The year 1950 was the most common "turning point" (17 states). 
Table 2. Year of Maximum Share of Manufacturing Earnings in Non-Farm Earnings by State

\begin{tabular}{|c|c|c|c|c|c|c|c|c|}
\hline & 1930 & 1940 & 1950 & 1960 & 1970 & 1980 & 1990 & 2000 \\
\hline New Englanc & & 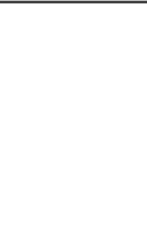 & $\begin{array}{l}\text { Connecticut } \\
\text { Maine } \\
\text { Massachusetts } \\
\text { New Hampshire } \\
\text { Rhode Island } \\
\text { Vermont }\end{array}$ & & & & & \\
\hline Mid Atlantic & & Maryland & $\begin{array}{l}\text { New Jersey } \\
\text { New York }\end{array}$ & $\begin{array}{l}\text { Delaware } \\
\text { Pennsylvania }\end{array}$ & & & & \\
\hline Great Lakes & & & $\begin{array}{l}\text { Illinois } \\
\text { Michigan } \\
\text { Ohio }\end{array}$ & $\begin{array}{l}\text { Indiana } \\
\text { Wisconsin }\end{array}$ & & & & \\
\hline Plains & & & & Missouri & & $\begin{array}{l}\text { lowa } \\
\text { Kansas } \\
\text { Minnesota } \\
\text { Nebraska }\end{array}$ & & $\begin{array}{l}\text { N. Dakota } \\
\text { S. Dakota }\end{array}$ \\
\hline Southeast & Florida & & $\begin{array}{l}\text { Louisiana } \\
\text { South Carolina }\end{array}$ & $\begin{array}{l}\text { Virginia } \\
\text { West Virginia }\end{array}$ & $\begin{array}{l}\text { Alabama } \\
\text { Georgia } \\
\text { Kentucky } \\
\text { North Carolina } \\
\text { Tennessee }\end{array}$ & $\begin{array}{l}\text { Arkansas } \\
\text { Mississippi }\end{array}$ & & \\
\hline Southwest & & & & & Texas & $\begin{array}{l}\text { Arizona } \\
\text { Oklahoma }\end{array}$ & $\begin{array}{l}\text { New } \\
\text { Mexico }\end{array}$ & \\
\hline $\begin{array}{c}\text { Rocky } \\
\text { Mountains }\end{array}$ & & & & $\begin{array}{l}\text { Colorado } \\
\text { Montana } \\
\text { Utah } \\
\text { Wyoming }\end{array}$ & & Idaho & & \\
\hline Far West & & & $\begin{array}{l}\text { Alaska } \\
\text { Hawaii } \\
\text { Nevada } \\
\text { Oregon }\end{array}$ & $\begin{array}{l}\text { California } \\
\text { Washington }\end{array}$ & & & & \\
\hline
\end{tabular}

Since the employment series begins in 1970, it conveys a truncated set of information about the role of manufacturing in regional and state employment. As shown in Figure 5, manufacturing employment is a declining share of total non-farm employment. Nationally, the range of the data declines from $21.6 \%$ in 1970 to $6.8 \%$ by 2017.

When considering the change in the share of manufacturing employment, the greatest declines were in the states with the highest starting levels: those in New England, the Mideast, the Great Lakes, and the Southeast. The smallest decline was in the Rocky Mountain region, which began 1970 with only $11 \%$ of its non-farm employment in manufacturing. 


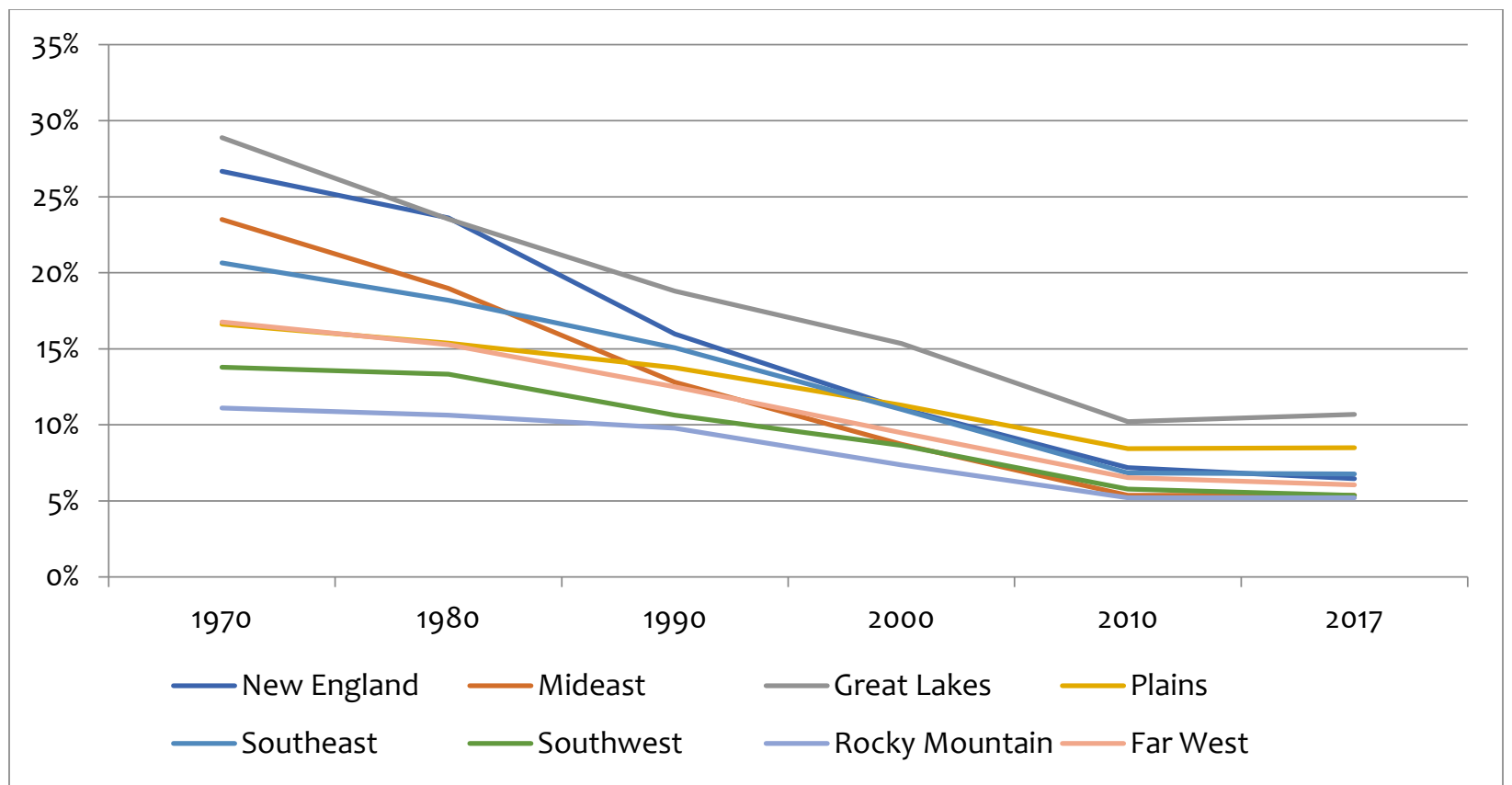

Figure 5. Share of Manufacturing in to Non-farm Employment by Region

Table 3 shows the year during which each state reached its maximum share of manufacturing employment in total non-farm employment. The vast majority of states reported the maximum share of manufacturing employment in 1970 due to the limitations of the data series. Five states reached their maximum in 1980 (Vermont, Kansas, Oklahoma, Utah, Alaska, and Nevada); two hit their maximum in 1990 (Mississippi and New Mexico), whereas North Dakota and South Dakota both reached their maximum in 2000. In general, the data presented here suggest that the manufacturing sectors of the states and regions are becoming more similar, i.e., are converging over time. 
Table 3. Year of Maximum Share of Manufacturing Employment in Non-Farm Employment by State

\begin{tabular}{|c|c|c|c|c|c|}
\hline & & 1970 & 1980 & 1990 & 2000 \\
\hline New England & $\begin{array}{l}\text { Connecticut } \\
\text { Maine } \\
\text { Massachusetts }\end{array}$ & $\begin{array}{l}\text { New Hampshire } \\
\text { Rhode Island }\end{array}$ & Vermont & & \\
\hline Mideast & $\begin{array}{l}\text { Delaware } \\
\text { Maryland } \\
\text { New Jersey }\end{array}$ & $\begin{array}{l}\text { New York } \\
\text { Pennsylvania }\end{array}$ & & & \\
\hline Great Lakes & $\begin{array}{l}\text { Illinois } \\
\text { Indiana } \\
\text { Michigan }\end{array}$ & $\begin{array}{l}\text { Ohio } \\
\text { Wisconsin }\end{array}$ & & & \\
\hline Plains & $\begin{array}{l}\text { lowa } \\
\text { Minnesota }\end{array}$ & $\begin{array}{l}\text { Missouri } \\
\text { Nebraska }\end{array}$ & Kansas & & $\begin{array}{l}\text { North Dakota } \\
\text { South Dakota }\end{array}$ \\
\hline Southeast & $\begin{array}{l}\text { Alabama } \\
\text { Arkansas } \\
\text { Florida } \\
\text { Georgia } \\
\text { Kentucky } \\
\text { Louisiana }\end{array}$ & $\begin{array}{l}\text { North Carolina } \\
\text { South Carolina } \\
\text { Tennessee } \\
\text { Virginia } \\
\text { West Virginia }\end{array}$ & & Mississippi & \\
\hline Southwest & Arizona & Texas & Oklahoma & New Mexico & \\
\hline $\begin{array}{c}\text { Rocky } \\
\text { Mountain }\end{array}$ & $\begin{array}{l}\text { Colorado } \\
\text { Idaho }\end{array}$ & $\begin{array}{l}\text { Montana } \\
\text { Wyoming }\end{array}$ & Utah & & \\
\hline Far West & $\begin{array}{l}\text { California } \\
\text { Hawaii }\end{array}$ & $\begin{array}{l}\text { Oregon } \\
\text { Washington }\end{array}$ & $\begin{array}{l}\text { Alaska } \\
\text { Nevada }\end{array}$ & & \\
\hline
\end{tabular}

\section{EMPIRICAL ANALYSIS}

Two model specifications were estimated to help explain the variation in manufacturing employment and compensation across states over time. The equations were estimated for data for all 50 states between 1970 and 2012. The reason for choosing that range was because right-to-work laws in U.S. states were fairly consistent during that period. In the period from 2012 and 2013, however, three additional states (Indiana, Michigan, and Wisconsin) enacted right-to-work legislation, with three additional states added to the list thereafter (West Virginia, Kentucky, and Missouri). Any attempt to control for that change would potentially create an endogeneity problem.

The following two parallel specifications were used to provide insights into the interstate variation in manufacturing employment and compensation, respectively:

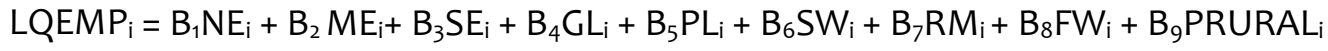

$$
\begin{aligned}
& +\mathrm{B}_{10} R T W_{i}+E^{\prime} \\
& L_{Q C O M P}=C_{1} N_{i}+C_{2} M E_{i}+C_{3} S_{i}+C_{4} G_{i}+C_{5} P_{i}+C_{6} S_{i}+C_{7} R M_{i}+C_{8} F W_{i}+C_{9} P R U R A L_{i} \\
& +C_{10} R_{T W}+E^{\prime \prime}
\end{aligned}
$$


where, for state i:

LQEMP $\mathrm{P}_{\mathrm{i}}=$ is the difference in a state's Location Quotient (LQ) for manufacturing employment between 2012 and 1970;

LQCOMP $_{i}=$ is the difference in a state's Location Quotient (LQ) for manufacturing compensation between 2012 and 1970;

$\mathrm{NE}_{\mathrm{i}}=\mathrm{A}$ regional dummy with a value of 1 if the state is in the Northeast Census Region and o otherwise; $M E_{i}=A$ regional dummy with a value of 1 if the state is in the Mideast Census Region and o otherwise; $\mathrm{SE}_{\mathrm{i}}=\mathrm{A}$ regional dummy with a value of 1 if the state is in the Southeast Census Region and o otherwise; $G L_{i}=A$ regional dummy with a value of 1 if the state is in the Great Lakes Census Region and 0 otherwise;

$\mathrm{PL}_{\mathrm{i}}=\mathrm{A}$ regional dummy with a value of 1 if the state is in the Plains Census Region and o otherwise;

$\mathrm{SW}_{\mathrm{i}}=\mathrm{A}$ regional dummy with a value of 1 if the state is in the Southwest Census Region and 0 otherwise;

$R M_{i}=A$ regional dummy with a value of 1 if the state is in the Rocky Mountain Census Region and 0 otherwise;

$\mathrm{FW}_{\mathrm{i}}=\mathrm{A}$ regional dummy with a value of 1 if the state is in the Far West Census Region and o otherwise;

PRURAL $L_{i}=$ the percentage of the population state i identified as rural in 2010;

RTWi $=$ a dummy with a value of 1 if the state is classified as a right-to-work state in 2010, while having a value of 0 otherwise; and

E', E" = stochastic error terms.

The location quotient variable for manufacturing employment is defined as:

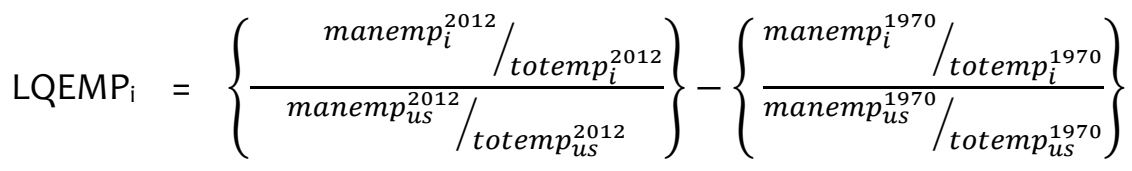

Where;

manemp ${ }_{i}^{y}=$ manufacturing employment in state I for year $y$,

totemp $p_{i}^{y}=$ total employment in state I for year $y$,

manemp ${ }_{u s}^{y}=$ manufacturing employment in U.S. for year $y$, 
totemp $\mathrm{us}_{\mathrm{u}}^{y}=$ total employment in U.S. for year $\mathrm{y}$.

A similar location quotient is used for the change in state manufacturing compensation over time.

The use of a location quotient as a dependent variable provides for a relative measure of the change in the importance of manufacturing employment over time while controlling for the overall trend in manufacturing employment in the U.S.

The models were estimated by OLS. The results for equations (1) and (2) are reported in Tables 4 and 5, respectively. The right-to-work law is reflected as a binary dummy (Cebula, 1980, 1989; Hogan, 1984).

The manufacturing employment Location Quotient equation (LQEMP, Table 4) has an $\mathrm{R}^{2}$ value of 0.71 and an F-statistic that tests significant at the 0.01 level. The coefficient on the percent of the population classified as rural tests significant at the 0.05 level and has a positive sign indicating that states with greater rural populations experienced in increase in their relative level of manufacturing employment between 1970 and 2012. That does not mean a state's manufacturing employment necessarily rose over the period but simply that their relative to the U.S. employment in manufacturing rose over the period. The right-to-work dummy variable tests significant at the .05 level and has the expected positive sign. Thus, states that had right-to-work laws in effect in 2012 appear to have experienced in increase in their relative level of manufacturing employment between 1970 and 2012.

The regional fixed-effects coefficients imply an interesting story concerning the regional shift in manufacturing employment. The Northeast, Mideast, and Plains regional dummy variables all test significant at the 0.05 level. They all exhibit a negative sign, which would indicate that states located within these regions were likely to experience a larger reduction in their relative manufacturing employment levels as compared to states in other regions between 1970 and 2012. By contrast, none of the other regional dummy variables tests as statistically significant, suggesting that states within these regions faired no differently than the average state over the 1970 to 2012 period.

The manufacturing compensation Location Quotient equation (LQCOMPi, Table 5) has an $\mathrm{R}^{2}$ value of 0.65 and an F-statistic that tests significant at the 0.01 level. The coefficient on the percent of the population classified as rural tests significant at the 0.05 level and has a positive sign, implying that states with greater rural populations experienced in increase in their relative level of manufacturing compensation between 1970 and 2012. This finding does not mean a state's manufacturing real compensation or real compensation per worker rose over the period but merely that their relative (to the U.S.) total manufacturing compensation rose over the study period. The right-to-work dummy variable also tests significant at the .05 level and has the expected positive sign. States that had rightto-work laws in effect in 2012 appear to have experienced in increase in their relative level of manufacturing compensation (vis-à-vis the U.S. as a whole) between 1970 and 2012. This is compatible with the studies by Newman (1983), Reed (2003), and Vedder (2010), among others, as well as the arguments in Stansel and McMahon (2013, Chapters 1and 3) and in Stansel, Torra, and McMahon (2018, Chapters 1 and 3).

The regional fixed-effects coefficients display a picture similar to that of the employment location quotient estimation. The Mideast regional dummy variable tests significant at the 0.05 level, and the Northeast regional dummy variable tests significant at beyond the 0.10 level. They both exhibit a negative sign, which would indicate that states located within these regions were likely to experience a larger reduction in their relative manufacturing compensation levels as compared to states in other regions between 1970 and 2012. None of the other regional dummy variables tests as statistically significant, which suggests that states within these regions faired no differently than the average state over the 1970 to 2012 study period. 
The results of these two estimations suggest an interesting pattern in the shift of manufacturing employment and compensation in the country over the past 40 years. In particular, the results imply that those regions of the country that have historically represented the manufacturing base have suffered the greatest relative loses in both employment and compensation between 1970 and 2012. In addition to regional location, it appears that two other factors (right-to-work laws and percent rural population) have also had the effect of leveling the manufacturing employment and compensation levels over the past 40 years (Reed, 2003; Vedder, 2010; Stansel and McMahon, 2013).

Table 6 presents the changes in manufacturing employment location quotients and manufacturing compensation location quotients between 1970 and 2010. In addition, the table also provides the manufacturing employment and manufacturing compensation location quotient change rank by state.

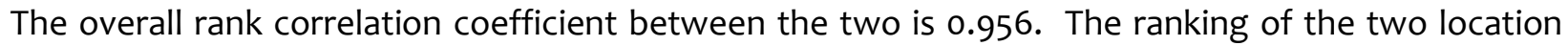
quotient changes is quite similar. Indeed, the only identifiable differences occur in the Southeast region, where the size in the decline of the employment location quotients was not followed by a decline in the compensation location quotients.

Table 4. Estimation Results for LQEMP

LS // Dependent Variable is LQEMP

Included observations: 50

\begin{tabular}{clllc}
\hline Variable & Coefficient & \multicolumn{1}{c}{ Std. Error } & t-Statistic & \multicolumn{1}{c}{ Prob. } \\
\hline NE & -0.390496 & 0.107937 & -3.617824 & 0.0008 \\
ME & -0.486974 & 0.092314 & -5.275196 & 0.0000 \\
SE & 0.077259 & 0.101974 & 0.757632 & 0.4531 \\
GL & 0.179848 & 0.125068 & 1.438002 & 0.1582 \\
PL & -0.270598 & 0.124853 & -2.167328 & 0.0362 \\
SW & -0.050150 & 0.127199 & -0.394262 & 0.6955 \\
RM & -0.087172 & 0.120214 & -0.725142 & 0.4726 \\
FW & 0.069065 & 0.087925 & 0.785492 & 0.4368 \\
RTW & 0.164281 & 0.080994 & 2.028321 & 0.0492 \\
PRURAL & 0.754841 & 0.229641 & 3.287042 & 0.0021 \\
R-squared & 0.708349 & Mean dependent var & & 0.139600 \\
Adjusted R-squared & 0.642728 & S.D. dependent var & & 0.324857 \\
S.E. of regression & 0.194174 & Akaike info criterion & & -3.101141 \\
Sum squared resid & 1.508147 & Schwarz criterion & & -2.718737 \\
Log likelihood & 16.581610 & F-statistic & & 10.794490 \\
Durbin-Watson stat & 2.180664 & Prob(F-statistic) & & 0.000000 \\
\hline
\end{tabular}


Table 5. Estimation Results for LQCOMP

LS // Dependent Variable is LQCOMP

Included observations: 50

\begin{tabular}{cllll}
\hline \multicolumn{1}{c}{ Variable } & Coefficient & \multicolumn{1}{c}{ Std. Error } & t-Statistic & \multicolumn{1}{c}{ Prob. } \\
\hline NE & -0.195817 & 0.106058 & -1.846309 & 0.0723 \\
ME & -0.478365 & 0.090708 & -5.273711 & 0.0000 \\
SE & 0.141631 & 0.100200 & 1.413484 & 0.1652 \\
GL & 0.127036 & 0.122892 & 1.033727 & 0.3075 \\
PL & -0.164168 & 0.122680 & -1.338178 & 0.1884 \\
SW & 0.018948 & 0.124986 & 0.151598 & 0.8803 \\
RM & -0.050314 & 0.118122 & -0.425948 & 0.6724 \\
FW & 0.068914 & 0.086395 & 0.797663 & 0.4298 \\
RTW & 0.184891 & 0.079584 & 2.323212 & 0.0253 \\
PRURAL & 0.495538 & 0.225645 & 2.196093 & 0.0339 \\
R-squared & 0.652301 & Mean dependent var & & 0.138191 \\
Adjusted R-squared & 0.574068 & S.D. dependent var & & 0.292346 \\
S.E. of regression & 0.190795 & Akaike info criterion & & -3.136251 \\
Sum squared resid & 1.456114 & Schwarz criterion & & -2.753847 \\
Log likelihood & 17.459360 & F-statistic & & 8.337994 \\
Durbin-Watson stat & 1.938013 & Prob(F-statistic) & & 0.000001 \\
\hline
\end{tabular}


Table 6. Results for Change in LQ Rank

\begin{tabular}{|c|c|c|c|c|c|c|c|c|c|}
\hline \multicolumn{10}{|c|}{ 2010-1970 Change in LQ Rank } \\
\hline State & LQEMP & Rank & LQCOMP & Rank & State & LQEMP & Rank & LQCOMP & Rank \\
\hline Alabama & 0.3259 & 14 & 0.3244 & 14 & Montana & 0.0702 & 29 & -0.0142 & 37 \\
\hline Alaska & 0.2249 & 21 & 0.0412 & 31 & Nebraska & 0.5484 & 5 & 0.3612 & 9 \\
\hline Arizona & 0.1301 & 26 & 0.2402 & 18 & Nevada & 0.2410 & 18 & 0.2268 & 21 \\
\hline Arkansas & 0.5184 & 6 & 0.3403 & 13 & New Hampshire & -0.0743 & $3^{8}$ & 0.1132 & 28 \\
\hline California & 0.1386 & 25 & 0.2244 & 22 & New Jersey & -0.5295 & 50 & -0.3779 & 48 \\
\hline Colorado & 0.0868 & 28 & 0.0549 & 30 & New Mexico & 0.2110 & 22 & 0.2087 & 24 \\
\hline Connecticut & -0.3211 & 47 & -0.1871 & 45 & New York & -0.3458 & 48 & -0.3844 & 49 \\
\hline Delaware & -0.4768 & 49 & -0.7099 & 50 & North Carolina & -0.1366 & 41 & 0.0055 & 35 \\
\hline Florida & -0.0289 & 34 & -0.0141 & 36 & North Dakota & 0.5063 & 7 & 0.4104 & 7 \\
\hline Georgia & -0.0501 & 36 & 0.0144 & 34 & Ohio & 0.0325 & 31 & 0.0297 & 32 \\
\hline Hawaii & 0.0001 & 33 & -0.0484 & 39 & Oklahoma & 0.3186 & 15 & 0.2648 & 17 \\
\hline Idaho & 0.3576 & 13 & 0.4005 & 8 & Oregon & 0.2677 & 17 & 0.3144 & 16 \\
\hline Illinois & -0.0860 & 39 & -0.0523 & 40 & Pennsylvania & -0.1919 & 43 & -0.1973 & 47 \\
\hline Indiana & 0.4202 & 10 & 0.5484 & 4 & Rhode Island & -0.2473 & 46 & -0.1690 & 44 \\
\hline lowa & 0.7261 & 2 & 0.5660 & 3 & South Carolina & -0.0359 & 35 & 0.1419 & 25 \\
\hline Kansas & 0.6851 & 3 & 0.6470 & 1 & South Dakota & 0.7428 & 1 & 0.5925 & 2 \\
\hline Kentucky & 0.4350 & 9 & 0.3580 & 10 & Tennessee & 0.0429 & 30 & 0.1306 & 27 \\
\hline Louisiana & 0.2398 & 19 & 0.3495 & 11 & Texas & 0.1709 & 23 & 0.2169 & 23 \\
\hline Maine & -0.1712 & 42 & -0.0288 & 38 & Utah & 0.4755 & 8 & 0.4842 & 6 \\
\hline Maryland & -0.2213 & 45 & -0.1881 & 46 & Vermont & 0.2291 & 20 & 0.2273 & 20 \\
\hline Massachusetts & -0.2114 & 44 & -0.0686 & 41 & Virginia & -0.0678 & 37 & -0.0930 & 43 \\
\hline Michigan & 0.0150 & 32 & 0.0757 & 29 & Washington & 0.2778 & 16 & 0.2279 & 19 \\
\hline Minnesota & 0.4070 & 11 & 0.3145 & 15 & West Virginia & -0.0926 & 40 & -0.0890 & 42 \\
\hline Mississippi & 0.3918 & 12 & 0.3488 & 12 & Wisconsin & 0.6536 & 4 & 0.5106 & 5 \\
\hline Missouri & 0.0947 & 27 & 0.0218 & 33 & Wyoming & 0.1654 & 24 & 0.1307 & 26 \\
\hline
\end{tabular}

\section{CONCLUSION}

This study seeks to explain empirically the disparate timing of state manufacturing earnings and employment decline as well as the shift among states in manufacturing earnings and employment. The results of two empirical estimations suggest an interesting pattern in the shift of manufacturing employment and compensation in the U.S. during the 1970 to 2012 time period. In particular, the empirical estimation results indicate that the regions of the country that have historically represented the manufacturing base have suffered the greatest relative loses in both employment and compensation during this period. In addition to regional location, it appears that two factors, namely, our de facto labor market freedom proxy variable, the right-to-work law dummy, along with the percent of state population classified as rural, have had the effect of leveling the manufacturing employment and compensation levels since 1970. In general, the estimations presented here suggest that the manufacturing sectors of the states and regions are becoming more similar over time. In other words, manufacturing activity that was once highly concentrated in the Great lakes, Northeast, and Mideast has now largely converged, with there being relatively little difference in concentration among the eight BEA regions. These findings confirm the significance associated with economic freedom measures observed by Murphy (2020) and Ghosh and McCannon (2017) and are compatible with Gallaway and Cebula (1973), Reed (2003), and Vedder (2010). They are also compatible with 
Stansel and McMahon (2013), where it is hypothesized that greater labor market freedom reduces labor market transactions costs and thereby promotes more employment, enhanced efficiency, and greater economic growth.

Indeed, as suggested above, following the 1970-2012 study period considered in this paper, three additional states, Indiana, Michigan, and Wisconsin, initially enacted right-to-work legislation, with three additional states added to the list of right-to-work states thereafter (West Virginia, Kentucky, and Missouri). This pattern would seem consistent with the characterization of right-to-work laws in this study as being recognized as a state-level public economic policy (acting through de facto increased labor market freedom). Thus, enhancing labor market freedom through the implementation of right-to-work laws appears to be a very straightforward means by which to improved generate economic and social outcomes.

In particular, it would appear that a circumspect adoption of RTW legislation would provide each state a policy tool that generates an opportunity to attract more capital, either in the form of new firms or in the expansion of firms already located within the state. Firms, especially those that are relatively more labor intensive, that seek to operate more cost-effectively and thereby more profitably by virtue of an increased presence in more efficiently functioning labor markets are the most likely to be attracted by the implementation of RTW laws. In theory, states adopting RTW legislation promote a more efficient exchange of labor services as well as an elevated present value for investment by private enterprise. Thus, the findings in this study would appear to be compatible with the findings and arguments in the alternative specification/modeling by Cebula (2014, p. 88), who found that “... it is typically expected that the greater the degree of economic freedom, the more successfully and efficiently markets perform and the greater the prosperity created through private enterprise." 


\section{REFERENCES}

Barro, R., and Sala-Martin, X. (1992). “Convergence," Journal of Political Economy, 100, 223-251.

Bureau of Economic Analysis. (2018A). "Compensation of Employees by Industry (SAINC6)" https://apps.bea.gov/itable/iTable.cfm?ReqID=70\&step=1\#

Bureau of Economic Analysis. (2018B). "Total Full-Time and Part-Time Employment by Industry (SAEMP25)" https://apps.bea.gov/itable/iTable.cfm?ReqID=70\&step=1\#

Bernard, A.B., and Jones, C.I. (1996). "Technology and Convergence," The Economic Journal, 106, 10371044 .

Broadberry, S.N. (1993). "Manufacturing and the Convergence Hypothesis," The Journal of Economic History," 53, 772-795.

Carree, M.A., Klomp, L., and Thurik, A.R. (2000). "Productivity Convergence in OECD Manufacturing Industries," Economics Letters, 66, 337-345.

Cebula, R.J. (1980). "A Theoretical and Empirical Analysis of Determinants of Geographic Living Cost Levels in the United States," Land Economics, 56, 477-481.

Cebula, R.J. (1989). “The Analysis of Geographic Living-Cost Differentials: A Brief Empirical Note," Land Economics, 65, 64-67.

Cebula, R.J. (2014). "The Impact of Economic Freedom and Personal freedom on Net Migration in the U.S.: A State-Level Empirical Analysis, 2000 to 2010,” Journal of Labor Research, 35 (1), 88-103.

Fingleton, B., and McCombie, J.S.L. (1998). "Increasing Returns and Economic Growth: Some Evidence for Manufacturing from the European Union Regions," Oxford Economic Papers, 50, 89-105.

Gallaway, L.E., and Cebula, R.J. (1973). "Differentials and Indeterminacy in Wage Rate Analysis: An Empirical Note," Industrial and Labor Relations Review, 26, 991-995.

Gatons, P., and Cebula, R.J. (1972). "Wage Rate Analysis: Differentials and Indeterminacy," Industrial and Labor Relations Review, 25, 207-212.

Ghosh, S., and McCannon, B.C. (2017). "Growth-Enhancing Economic Freedom,” Journal of Financial Economic Policy, 9, 209-224.

Glaeser, Edward L., and Tobio, Kristina. (2008). "The Rise of the Sunbelt," Southern Economic Journal, 74 (3), 609-643.

Hicks, Michael J., LaFaive, Michael, and Devaraj, Srikant. (2016). "New Evidence on the Effect of Right-toWork Laws on Productivity and Population Growth," Cato Journal, 36(1), 101-121.

Hogan, T.D. (1984). "Geographic Living-Cost Differentials in the United States: A Disaggregated View," Land Economics, 65, 115-119.

Kane, R. (2001). "Investigating Convergence of the U.S. Regions: A Time-Series Analysis," Journal of Regional Analysis and Policy, 31, 1-22.

Madsen, J.B., and Timol, I. (2011). "Long-Run Convergence in Manufacturing and Innovation-Based Models," The Review of Economics and Statistics, 93, 1155-1171.

Martin, R., and Sunley, P. (1998). "Slow Convergence? The New Endogenous Growth Theory and Regional Development," Economic Geography, 74, 201-227.

Martin, W., and Mitra, D. (2001). "Productivity Growth in Agriculture versus Manufacturing," Economic Development and Cultural Change, 49, 403-422.

Miketa, A., and Mulder, P. (2005). "Energy Productivity across Developed and Developing Countries in 10 Manufacturing Sectors: patterns of Growth and Convergence," Energy Economics, 27, 429-453.

Murphy, R. (2020). "Economic Freedom Variables Endogenous to Business Cycles," Journal of Financial Economic Policy, 12, 65-75.

Newman, Robert J. (1983) "Industry Migration and Growth in the South." Review of Economics and Statistics 65 (1), 76-86. 
Quah, D. (1993). “Empirical Cross-Section Dynamics in Economic Growth,” European Economic Journal, 37, 426-434.

Reed, W. Robert. (2003). "How Right-to-Work Laws Affect Wages," Journal of Labor Research, 24, 713-730.

Rodrik, D. (2013). "Unconditional Convergence in Manufacturing," The Quarterly Journal of Economics, $128,165-203$.

Stansel, D., and McMahon, F. (2013). Economic Freedom of North America, 2013. Vancouver: The Fraser Institute.

Stansel. D., Torra, J., and McMahon, F. (2018). Economic Freedom of North America, 2018. Vancouver: The Fraser Institute.

Sherwood-Call, C. (1996). "The 1980s Divergence in State per Capita Incomes: What Does It Tell Us?" Economic Review - Federal Reserve Bank of San Francisco, 41, 14-24.

Stevans, Lonnie K. (2009). "The Effect of Endogenous Right-to-Work Laws on Business and Economic Conditions in the United States: A Multivariate Approach," Review of Law \& Economics, 5(1), 595-614.

Togo, K. (2002). “Productivity Convergence in Japan's Manufacturing Industries," Economics Letters, 75, 61-67.

Tomiura, A. (1997). "Productivity in Japan's Manufacturing Industry," International Journal of Production Economics, 52, 239-246.

Vedder, Richard K. (2010). "Right-to-Work Laws: Liberty, Prosperity, and Quality of Life," Cato Journal, 30(1), 171-180.

Vedder, Richard K. (1976). The American Economy in Historical Perspective. New York: Wadsworth Publishing.

Weber, W.L.., and Domazlicky, B.R. (2006). "Capital Deepening and Manufacturing's Contribution to Regional Economic Convergence," Journal of Regional Analysis and Policy, 36, 31-44. 